\title{
Chemical characterization of particle emissions from controlled burns of biomass fuels using a high resolution time-of-flight aerosol mass spectrometer
}

L. Qi ${ }^{1,2}$, S. Hosseini ${ }^{3}$, H. Jung ${ }^{3}$, B. Yokelson ${ }^{4}$, D. Weise ${ }^{5}$, D. Cocker $\mathrm{III}^{1}$, and Y. Huang ${ }^{2}$

${ }^{1}$ Department of Chemical and Environmental Engineering, Bourns College of Engineering, Center for Environmental Research and Technology (CE-CERT), University of California, Riverside, CA 92507, USA

${ }^{2}$ State Key Laboratory of Dioxin Pollution Control, National Research Center for Environmental Analysis and Measurements, Beijing 100029, China

${ }^{3}$ Department of Mechanical Engineering, Bourns College of Engineering, Center for Environmental Research and Technology (CE-CERT), University of California, Riverside, CA 92507, USA

\footnotetext{
${ }^{4}$ Department of Chemistry, University of Montana, Missoula, MT 59812, USA

${ }^{5}$ Foreset Fire Laboratory, 4955 Canyon Crest Drive, Riverside, CA 92507, USA

Received: 28 February 2012 - Accepted: 7 March 2012 - Published: 29 March 2012

Correspondence to: L. Qi (luciaqi@gmail.com), D. Cocker (dcocker@engr.ucr.edu)

Published by Copernicus Publications on behalf of the European Geosciences Union.
} 
Abstract

A total of forty-nine burns were conducted at the Missoula Fire Sciences Lab consisting of nine fuel types; i.e., chamise scrub oak, ceanothus, maritime chaparral, coastal sage scrub, California sage brush, Manzanita, oak savanna, oak woodland and masticated

5 mesquite. This paper focuses on the chemical characterization of fine particle emissions collected for flaming, mixed and smoldering phases using a HR ToF-AMS. The evolution of $\mathrm{OM} / \mathrm{OC}, \mathrm{H} / \mathrm{C}, \mathrm{O} / \mathrm{C}$ and $\mathrm{N} / \mathrm{C}$ from fire ignition to extinction was measured to capture the transient and integrated chemical composition of the non-refractory portion of bulk particles. Real time elemental ratios and empirical formulas derived with

10 respect to modified combustion efficiency (MCE) are reported. For each fuel, the hydrogen fragment ions dominate the unit mass resolution (UMR) mass spectra with no specific fragment ions attributable to an individual ecological combination. An interference ion in the UMR $\mathrm{m} / \mathrm{z} 73$, a fragment normally attributed to levoglucosan, is noted. Therefore, the results imply that $\mathrm{C}_{2} \mathrm{H}_{4} \mathrm{O}_{2}^{+}\left(\mathrm{m} / \mathrm{z}\right.$ 60.021) plus $\mathrm{C}_{3} \mathrm{H}_{5} \mathrm{O}_{2}^{+}(\mathrm{m} / \mathrm{z}$ 73.029) are 15 more sufficient to estimate the contribution of levoglucosan. The results did not show significant variations of levoglucosan content in the organic particle with the overall average contribution fraction ranging from $0.74 \%$ for coastal sage to $1.93 \%$ for chamise.

\section{Introduction}

Biomass combustion emissions contribute significantly to aerosol species in the at20 mosphere (Crutzen and Andrea, 1990). Particle emissions mainly arise from natural fires, prescribed burns, and residential wood combustion, which contribute to climatic impacts, regional visibility reduction and potential health hazards (Naeher et al., 2007, Watson, 2002). Although biomass burning emissions in the United States are reported to account for only 5\% of annual average emissions (van der Werf et al., 2006), they

25 play a significant role in urban and regional air quality (McMeeking et al., 2006; Park et al., 2006, 2007; Robinson et al., 2006). Park et al. (2007) estimated that biomass

$$
8399
$$

burning contributed approximately $50 \%$ of the annual mean total particulate carbon concentration within the US, and that summer wildfires drove the greatest variability in observed total particulate carbon. In addition, wood smoke emissions from wildfires and prescribed burns are responsible for occasional severe episodes of air pollution

5 (Fraser and Lakshmanan, 2000; Phuleria et al., 2005). Prescribed burns are carried out to protect manmade structures, residential communities and the natural pattern of an ecological system. With the frequency and magnitude of wildfires increasing in some regions, it is expected that the demand for prescribed burns will increase in vulnerable regions, resulting in enhanced impacts from biomass burns (Spracklen et al., 10 2007; Haines et al., 2001).

Models require information input including burned area, fuel loading inventories and fuel-based emission factors (EFs) to estimate fire emissions and their impacts. Emission factors are defined as the mass of a chemical species emitted to the mass of fuel burned (e.g. Schultz et al., 2008; Wiedinmyer et al., 2006). EFs have been extensively 15 measured in the laboratory and field in the past 40 years; however, there remains a significant uncertainty and variability in estimates from different geographic regions (Schultz et al., 2008; Wiedinmyer et al., 2006). Andrea and Merlet (2001) compiled EFs for three ecosystem types: savanna and grassland, tropical forests and extratropical forests based on a full literature review. However, the recommended values

20 did not necessarily reflect the specific fuel types and combustion conditions. Battye and Battye (2002) also summarized previous work on EFs that has been applied to field studies, primary emissions from fires in forest regions in the northwestern US and Alaska, as well as chaparral fires in southeastern US (Cofer et al., 1988a, b; Friedli et al., 2001; Hays et al., 2002; Muhle et al., 2007; Yokelson et al., 1999). While field stud25 ies have the advantage of measuring emissions from real fires, controlled laboratory studies are used to fill in informational gaps in burn time, space and combustion phase. Some laboratory studies of biomass fuel burns have been published (Chakrabarty et al., 2006; Chen et al., 2006, 2007; Hays et al., 2002), but measurements of emission from individual chaparral or southwestern US plant species are very rare (McMeeking 
et al., 2009).

The research program took place at the US Forest Service's Fire Sciences Laboratory at Missoula, Montana. We deployed a comprehensive suite of measurements that include both gas-phase and speciated particle-phase emissions. More specif-

5 ically, for biomass burning smoke aerosol, real-time particle size distribution, number and volume concentrations, total surface area, and elemental composition are measured simultaneously with filter and other substrate sampling for offline analysis. This paper herein focuses on the chemical composition analysis using high-resolution time-of-flight aerosol mass spectrometer (HR ToF-AMS). The elemental ratios (organic 10 matter/organic carbon $(\mathrm{OM} / \mathrm{OC})$, oxygen/carbon $(\mathrm{O} / \mathrm{C})$, hydrogen/carbon $(\mathrm{H} / \mathrm{C})$, nitrogen/carbon (N/C)), mass spectra, and levoglucosan analysis for nine southwestern US plant species during flaming, mixed and smoldering phases are presented. The high resolution mass spectra of organic aerosol reported in this paper contribute to fill the lack of chemical information on southwestern US biomass fuel burnings.

\section{Experimental section}

\subsection{Fuel selection and treatment}

Fuel characterization and fuel bed configuration are very important parameters to determine particle emissions. In this study, a total of 49 burns, consisting of 9 different types of southwestern US plant species representative of this ecosystem (Table 1), 20 were conducted individually.

Samples of Chamise and Ceanothus were collected from Ft. Hunter-Liggett (CA), about $400 \mathrm{~km}$ northwest to Los Angeles. Samples of Manzanita, California sage, coastal sage and maritime chaparral were collected from Vandenberg Air Force Base (CA), about $250 \mathrm{~km}$ northwest to Los Angeles. Samples of oak savanna, oak woodland 25 and mesquite were collected from Ft. Huachuca (AZ), about $900 \mathrm{~km}$ southeast to Los Angeles. These fuels represent chaparral and oak woodland from southwestern US.

8401

Clinton et al. (2006) estimated that $\sim 80 \%$ of the fuels consumed by major wildfires in southern California in 2003 were attributable to shrubs and duffs. Bulk characteristics of the fuel beds are listed in Table 2. Average moisture content (oven-dry mass basis, ASTM D4442-07) of the fuel beds at the time of burning ranged from $4 \%$ to $33 \%$, sim-

5 ilar to fuel moisture in dead fuels. The initial oven-dry mass in the fuel beds ranged from $670 \mathrm{~g}$ to $4630 \mathrm{~g}$. Bulk density of the fuel beds ranged from 5.8 to $14 \mathrm{~kg} \mathrm{~m}^{-3}$ and the packing ratio (defined as the ratio of fuel bulk density to fuel density) ranged from 0.01 to 0.024 . These packing ratios for the southwestern fuels are similar to those reported for laboratory fire spread experiments (Weise et al., 2005), but 1 to 2 orders of magni-

10 tude larger than packing ratios observed in the field. 18 out of 49 fuel beds (Chamise, Ceanothus, manzanita, and California sagebrush) were ignited using a propane torch with the aid of small amount of isopropyl alcohol. The rest of the burns were initiated with the propane torch only. The fuel arrangement for burning significantly affected fuel consumption. We attempted to arrange the Chamise/scrub oak fuels vertically as found

15 in nature (Fig. 1a), but the fire did not spread well resulting in an average consumption of $30 \%$ for this fuel type. Therefore, the fuel beds were arranged horizontally (Fig. 1b) with up to $90 \%$ of fuel consumed except for Ceanothus.

\subsection{Combustion facility}

All the experiments were conducted in the combustion laboratory at the US Forest Ser20 vice's Fire Science Laboratory (FSL), Missoula, MT, (schematic displayed in Fig. 2). Detailed descriptions can be found elsewhere (Yokelson et al., 1996). In short, the main combustion room measures $12.5 \mathrm{~m} \times 12.5 \mathrm{~m} \times 22 \mathrm{~m}$ in height. The stack is located at the room center, $2.1 \mathrm{~m}$ above the ground and extends through the ceiling. The combustion exhaust is vented via a $3.6 \mathrm{~m}$ diameter hood attached to a $1.6 \mathrm{~m}$ di-

25 ameter stack. Sampling ports that position near the center of the exhaust flow and pass through the walls of the stack are located about $16.5 \mathrm{~m}$ above the floor. The instruments were deployed on a platform surrounding the stack at the same height as the sampling ports. The lab is slightly pressurized with pre-conditioned outside air to 
precisely control temperature, and relative humidity. The air velocity in the chimney was set to $1.5 \mathrm{~m} \mathrm{~s}^{-1}$ or $3 \mathrm{~m} \mathrm{~s}^{-1}$ by controlling the exhaust fan speed to maintain proper entrainment of fresh air.

\subsection{Real-time particle measurements}

5 A dilution sampler was used to cool the samples prior to injection into the online instruments. In brief, an isokinetic sampling probe was inserted in the stack center. The sample flow was then diluted using a partial flow dilution system with a single venturi (Agrawal et al., 2008). A 13.5:1 dilution ratio was determined using $\mathrm{CO}$ as a tracer. Dilution house air was treated with silica gel $\rightarrow$ charcoal denuder $\rightarrow$ HEPA in series.

10 The diluted aerosol flow then passed through a $\mathrm{PM}_{10}$ impactor to remove large particles before distributing the sample flow to the HR-ToF-AMS and other online particle measurement instruments. Figure 3 depicts the schematic flow chart of sampling system in detail. This paper herein presents the results of chemical analysis of organic particle species from HR ToF-AMS for each individual fuel. The instrument operated in

15 the high resolution mode and has been described in detail previously (deCarlo et al., 2006). More recently, a new elemental analysis (EA) technique was developed using HR-ToF-AMS sampling data (Aiken et al., 2007; 2008). In this study, the C:O:H ratio of the total aerosol was determined using the high resolution capabilities of the HR-ToFAMS following the Peak Integration by Key Analysis (PIKA) and Analytical Procedure 20 for Elemental Separation (APES) templates (deCarlo et al., 2006, Aiken et al., 2008).

\subsection{Real-time gas measurement}

Fire integrated modified combustion efficiency (MCE) has been widely used in previous studies to describe combustion conditions. MCE is defined as the molar ratio of the emitted $\mathrm{CO}$ and $\mathrm{CO}_{2}$ (Ward and Radke, 1993) and calculated as below,

$25 \mathrm{MCE}=\frac{\left[\Delta \mathrm{CO}_{2}\right]}{\left[\Delta \mathrm{CO}_{2}\right]+[\Delta \mathrm{CO}]}$

where $\left[\Delta \mathrm{CO}_{2}\right]$ and $[\Delta \mathrm{CO}]$ are the excess molar mixing ratios of $\mathrm{CO}_{2}$ and $\mathrm{CO}$. For stack smoke, MCE was calculated for each burn by dividing the total mass of $\mathrm{CO}_{2}$ emitted by the net mass of $\mathrm{CO}_{2}$ plus CO emitted. Ward and Radke (1993) classified combustion conditions into three phases based on MCE i.e. flaming when MCE > 0.97; mixed state 5 when $0.85<\mathrm{MCE}<0.97$; smoldering when $0.75<\mathrm{MCE}<0.85$. Real-time $\mathrm{CO}$ and $\mathrm{CO}_{2}$ measurements were made using an Open-Path Flourier Transform Infrared (OP-FTIR) spectrometer.

\section{Results and discussions}

\subsection{Modified combustion efficiency}

10 We attempted to segregate the mode of combustion during each burn using instantaneous MCE value and other indicators while some other studies report combustion conditions by using integrated or averaged MCE over the entire burn. Accordingly, the combustion process was segregated into three phases, i.e. flaming, mixed and smoldering. Fire-integrated mean MCE values for selected burns covering all 9 vege-

15 tation ranged from $0.98-1.0,0.871-0.912$, and $0.817-0.9$ with standard deviation from $0.008-0.049,0.026-0.049$, and $0.008-0.036$ for flaming, mixed and smoldering periods, respectively. The MCE results are displayed in Fig. 4. The fuel moisture content is below $15 \%$ except for oak woodland. However, we do not observe a dependence of MCE on fuel moisture as reported in other study (McMeeking et al., 2009) for the

20 fuel moisture content less than $15 \%$. Regards to the medium level of fuel moisture, the oak woodland appears to have the lowest MCE during flaming phase and highest MCE during the mixed and smoldering phases.

\subsection{Mass spectra from different fuel combustion}

Figure 5 shows the average unit mass resolution (UMR) mass spectra of organics, ni25 trate, sulfate, ammonia and chloride throughout flaming, mixed and smoldering phases 
of burn for the nine southwestern biomass fuels. One burning experiment was selected for each type of fuel and each $\mathrm{m} / \mathrm{z}$ was normalized to the total organic mass.

Since the majority of particle mass are emitted during flaming and mixed phases, the mass spectra pattern of relative intensity under these particular combustion con-

5 ditions more closely represents the results of the entire burn. Generally, the hydrocarbon fragment ions $\mathrm{C}_{n} \mathrm{H}_{2 n-1}^{+}$such as $\mathrm{C}_{3} \mathrm{H}_{5}^{+}$at $m / z 41, \mathrm{C}_{4} \mathrm{H}_{7}^{+}$at $\mathrm{m} / \mathrm{z} 55$ and $\mathrm{C}_{5} \mathrm{H}_{9}^{+}$ at $m / z 69$ and $\mathrm{C}_{n} \mathrm{H}_{2 n+1}^{+}$such as $\mathrm{C}_{2} \mathrm{H}_{5}^{+}$at $m / z 29, \mathrm{C}_{3} \mathrm{H}_{7}^{+}$at $m / z 43, \mathrm{C}_{4} \mathrm{H}_{9}^{+}$at $m / z 57$ significantly dominate the $\mathrm{m} / \mathrm{z}$ patterns for all fuels. The observations are consistent with those reported by Weimer et al. (2008) for the European forest and residential

10 wood types using quadruple-AMS (Q-AMS). However, differences in the mass spectral characteristics varied by fuel type. In summary, the mass spectra of particle emissions is characterized by the fragment $\mathrm{m} / \mathrm{z} 44\left(\mathrm{CO}_{2}^{+}\right)$predominant possibly owing to decarbonxylation of oxo- and di-carboxylic acids (Alfarra et al., 2006) for the coastal sage, California sage, oak savanna and Manzanita. The reason could be that when there 15 are still a lot of biopolymers such as cellulose and lignin available indicated by the hydrocarbon fragments while more readily oxidized organics are found simultaneously due to the easy and fast combustion properties of these fuels. In addition, Andrea and Merlet (2001) stated that the flaming phase can exhibit strong variation depending on different internal parameters such as moisture. There is a significant contribution 20 of chloride emission during the flaming phase for all the fuels with the exception of oak woodland. Maritime chaparral and California sage scrub have the highest fractions. When the fire goes to mixed phase, dramatic decrease in chloride emission was observed in Ceanothus and Chamise compared to the other six fuels. For sulfate emission, maritime chaparral, California sage scrub, Chamise, Manzanita, mesquite, oak woodland have higher contribution fractions than coastal sage brush, Ceanothus, and oak savanna. During the mixed phase, only Manzanita and California sage scrub have decent amount of sulfate emitted, indicating that the majority of sulfur containing compound in the other fuels burned rapidly and emitted instantaneously as the fire lid. The emissions of nitrate and ammonia seem to occur and maintain relatively the same

\section{5}

level in both phases for most of the fuels. When the fire goes to smoldering phase, organics become dominant while all the inorganic species fade significantly.

The relative contributions of $\mathrm{m} / \mathrm{z} 29,43,44,60$ and 73 to the total organic mass were shown in Table 3 to evidently reveal the chemical composition of all fuel types. No sub5 stantial difference is seen for all the fuel types with an exception of higher $\mathrm{m} / \mathrm{z} 44$ and lower $\mathrm{m} / \mathrm{z} 29$ fractions for Manzanita case. A highest and lowest content of levoglucosan reflected by $m / z 60$ and 73 were observed for oak savanna and sage species, respectively. More details will be discussed in later section. Additionally, the mass spectra from all biomass fuel types do not hint to a specific mass spectral signature 10 that can be used exclusively for a specific species assignment.

\subsection{Elemental ratios}

Elemental carbon (EC) and organic carbon (OC) emission factor from many biomass fuels has been extensively characterized earlier (Hays et al., 2005; Mazzoleni et al., 2007; Habib et al., 2008; Mcmeeking et al., 2009) as bulk chemical analysis of car-

15 bonaceous aerosol. This work reports new measurements of bulk chemical composition of organic carbonaceous species using HR-ToF-AMS. As a result of the extensive fragmentation caused by electron impact ionization and the thermal decomposition of molecules by the vaporizer, most of the signal intensity in the HR-ToF-AMS occurred below mass to charge ratio $(\mathrm{m} / \mathrm{z})$ 100; parent molecular peaks were weak or unob20 served. Therefore, the EA was conveniently applied to the data set of collected samples and interpreted as bulk chemical composition. To the author's best knowledge, this is the first time that real time elemental ratios and empirical formula derived with respect to MCE have been reported. 
The average elemental ratios for each fuel during flaming, mixed and smoldering are then derived and displayed in Fig. 6 . The $\mathrm{O} / \mathrm{C}$ ratio during flaming periods ranged from $0.2-0.476$ with standard deviation of $0.051-0.090$. The $\mathrm{H} / \mathrm{C}$ ratio ranged from $1.435-$ 1.764 with standard deviation of $0.068-0.108$. The $\mathrm{N} / \mathrm{C}$ ratio ranged from $0.026-0.325$

5 with standard deviation of $0.005-0.165$. Similarly, the mean $\mathrm{O} / \mathrm{C}, \mathrm{H} / \mathrm{C}$ and N/C are $0.17-0.432$, 1.484-1.713 and 0.024-0.377, respectively for mixed phase. And the ratios during the smoldering phase are found to be $0.155-0.372,1.493-1.749$ and $0.070-0.519$, respectively. Note that the MCE of oak savanna remained high during the entire burn; there is no obvious smoldering phase for that fuel species. The empir-

10 ical formulas of organic carbonaceous aerosol derived from EA from each fuel during different combustion phases were summarized in Table 4. In general, the $\mathrm{O} / \mathrm{C}$ and $\mathrm{H} / \mathrm{C}$ ratios are close for the flaming, mixed and smoldering phases, while N/C ratio varies with higher uncertainty. The possible reason can be attributed to the distinct behavior that nitrogen element participates in the combustion process under different conditions.

15 Overall, the Rangeland ecosystem group including California sage brush and California sage scrub show the highest oxygen content level. The Chaparral ecosystem group which contains Ceanothus, Chamise and Manzanita has lower O/C during the flaming phase while higher oxygen content level during the mixed phase compared to the Coastal plain ecosystem including oak savanna and oak woodland.

$20 \quad 3.4$ Significance tests of combustion phase and fuel type effects on elemental ratios

Using the elemental ratios of $\mathrm{O} / \mathrm{C}, \mathrm{H} / \mathrm{C}$ and $\mathrm{N} / \mathrm{C}$ estimated in the previous section which consisted of two replications of the nine fuel types, the univariate test analysis was performed. Mean values of each ratio were calculated for each combustion phase

25 (flaming, mixed, smoldering) of the 18 fires (duplicate of 9 fuel types) and used in the analysis.

Multivariate analysis of variance was used to test the effects of combustion phase and fuel type on the elemental ratios singularly (univariate) and collectively 8407

(multivariate). Specific hypotheses were formulated for fuel type as follows: (1) elemental ratios for hard chaparral (chamise/scrub oak, Manzanita, ceanothus, and maritime chaparral) are equal. (2) elemental ratios for hard chaparral and soft chaparral (coastal sage scrub, California sagebrush) are equal. (3) elemental ratios for hard chaparral 5 and Emory oak woodland are equal. (4) elemental ratios for Emory oak woodland and Emory oak savanna are equal. Similarly, hypotheses for combustion phase were proposed as follows: (1) elemental ratios for flaming and smoldering phases are equal. The probability level set to determine significance of the various statistical tests was 0.05 . If the probability value associated with the test statistic was less than 0.05 , the 10 null hypothesis of no effect was rejected. A large number of hypothesis tests were performed so that only a summary of the tests are presented below.

For the univariate tests, the mean elemental ratios were significantly affected by the combustion phase for all 4; however, only the N/C ratio differed significantly between the flaming and smoldering phases. When considered collectively, the flaming phase differed from the smoldering and mixed phases.

Fuel type effects on elemental ratios were somewhat more complicated. When tested individually, the OM/OC ratio did not differ between fuel types. The O/C and $\mathrm{H} / \mathrm{C}$ ratios generally did not differ between fuel types; however, they did differ between the hard and soft chaparral fuel types collected at Vandenberg AFB. The N/C ratio also

20 differed between the hard chaparral fuel types. When viewed collectively, the emission ratios differed between hard and soft chaparral.

\subsection{Levoglucosan analysis}

Levoglucosan (1,6-anhydro-b-D-glucopyranose), a cellulose combustion product, has been reported as a biomass burning tracer (Simoneit et al., 1999, 2002) due to its high 25 resistance to degradation in the ambient atmosphere (Fraser and Lakshmanan, 2000). Some of the levoglucosan is consumed in various reactions during combustion; nevertheless, it is emitted in large quantities and results in the presence in the particle-phase of smoke. Levoglucosan is source-specific to any fuel type that contains cellulose; 
therefore, it can be used as a specific tracer for the particulate emissions from biomass burning. Increasing effort has been put into levoglucosan quantification methodology development in recent years, which are roughly quantified using either gas chromatography (GC) or liquid chromatography. But these conventional methods require long 5 preparation of samples, expensive cost and derivatization treatment in some cases.

More recently, advanced instrumentation has been developed among which the HRToF-AMS addresses the most extensive application. Alfarra et al. (2007) have recently identified specific marker fragments for wood-burning particle emissions using a quadruple-AMS (Q-AMS). Results showed that the contribution of mass fragments

1060,73 and 137 to the total organic mass were enhanced during evening periods relative to morning periods and were therefore suggested to be marker fragments for wood-burning particle emissions.

With the capability of high-resolution module, the ion fragment identification can be improved even more than the UMR mass spectra. The cleavage of the levoglucosan 15 molecule by El ionization gives the major fragmented ions of $\mathrm{C}_{2} \mathrm{H}_{4} \mathrm{O}_{2}^{+}$at $\mathrm{m} / \mathrm{z} 60$ and $\mathrm{C}_{3} \mathrm{H}_{5} \mathrm{O}_{2}^{+}$at $\mathrm{m} / z$ 73. However, $m / z 73$ is observed to contain two fragmented ions, i.e. $\mathrm{C}_{3} \mathrm{H}_{5} \mathrm{O}_{2}^{+}$and $\mathrm{C}_{3} \mathrm{H}_{7} \mathrm{NO}^{+}$as shown in Fig. 7 for some fuel types. Therefore, it is inaccurate to use UMR $m / z 73$ as marker fragment for biomass burns as opposed to $\mathrm{C}_{3} \mathrm{H}_{5} \mathrm{O}_{2}^{+}$ ion. And thus the time evolution of $\mathrm{C}_{2} \mathrm{H}_{4} \mathrm{O}_{2}^{+}$and $\mathrm{C}_{3} \mathrm{H}_{5} \mathrm{O}_{2}^{+}$vs. total organics throughout

20 flaming, mixed and smoldering phases is illustrated in Fig. 8 to manifest the variation of levoglucosan content at different phases of biomass burning. The contour plot starts with flaming period labeled with dark color and then goes to lighter color as the fire approaches to smoldering phase. Overall, the $\mathrm{C}_{2} \mathrm{H}_{4} \mathrm{O}_{2}^{+}$follows a linear relationship with total organics except for oak savanna. Ceanothus has the highest levoglucosan contribution fraction followed by oak woodland, Chamise and maritime chaparral. Oak savanna, Manzanita and mesquite have intermediate levels while California sage and coastal sage have the lowest content of levoglucosan in emitting particles. Similar phenomena were also observed for the evolution of $\mathrm{C}_{3} \mathrm{H}_{5} \mathrm{O}_{2}^{+}$ion. The overall contribution of $\mathrm{C}_{2} \mathrm{H}_{4} \mathrm{O}_{2}^{+}$plus $\mathrm{C}_{3} \mathrm{H}_{5} \mathrm{O}_{2}^{+}$as indicative of levoglucosan to the total organic mass ranges

8409

from $0.75 \%-2.46 \%$. Generally, they follow the linear relationship well with $\mathrm{C}_{3} \mathrm{H}_{5} \mathrm{O}_{2}^{+}$ universally lower than $\mathrm{C}_{2} \mathrm{H}_{4} \mathrm{O}_{2}^{+}$.

\section{Conclusions}

We characterized real-time organic particle elemental ratios using HR-ToF-AMS from 5 the laboratory scale biomass burns for a variety of southwestern US biomass fuels. The evolution of $\mathrm{OM} / \mathrm{OC}, \mathrm{H} / \mathrm{C}, \mathrm{O} / \mathrm{C}$ and $\mathrm{N} / \mathrm{C}$ from fire ignition to extinction was measured to capture the transient and integrated chemical composition of the non-refractory portion of bulk particles. Time averaged elemental ratios were segregated into three combustion modes: flaming, mixed and smoldering which are classified based on the MCE

10 values. In general, the particle concentrations were highest during flaming phase and then gradually decreased during mixed and smoldering phase. For each fuel, the hydrogen fragment ions dominate the UMR mass spectra and no specific fragments exhibit that can be assigned to an intrinsic type of species. Significance tests indicated that the elemental ratios were affected by the combustion phases and fuel types. High

15 resolution of $\mathrm{m} / \mathrm{z} 60$ and 73 supposingly designated to levoglucosan has been resolved for biomass marker validation. The results imply that using $\mathrm{C}_{2} \mathrm{H}_{4} \mathrm{O}_{2}^{+}$plus $\mathrm{C}_{3} \mathrm{H}_{5} \mathrm{O}_{2}^{+}$to estimate the contribution of levoglucosan in the future may be more sufficient.

Our investigation showed that one can refer to real time chemical information under different burning conditions (flaming, mixed and smoldering) by using the HR ToF-AMS.

20 The nitrogen containing fraction gives the most fluctuation for some vegetations, which could possibly be attributed to the different elemental abundance of the plant species or the uncertainty of elemental analysis method applied to the data sets. For the future, therefore, further investigations are needed to relate the chemical characteristics of particle emissions with the biofuel elemental properties.

25 Acknowledgements. This research described in this paper has been funded by US Department of Defense Strategic Environmental Research and Development Program (SI-1647, SI-1648, and $\mathrm{SI}-1649$ ) and partially financial supported by the National Basic Research Program of 
China (2009CB421602) and National Department Public Benefit Research Foundation of China (200909095), which have not endorsed this publication and the views expressed herein may not reflect their views. Authors are grateful to lan Burling for FTIR data and WeiMin Hao, Shawn Urbanski, Cyle Wold, Joey Chong, Trevor Maynard and Emily Lincoln for their help.

\section{References}

Agrawal, H., Malloy, Q., Welch, W., Miller, W., and Cocker, D.R. III: In-use gaseous and particulate matter emissions from a modern ocean going container vessel, Atmos. Environ., 42, 5504-5510, 2008.

Aiken, A. C., DeCarlo, P. F., and Jimenez, J. L.: Elemental analysis of organic species with 10 electron ionization high-resolution mass spectrometry, Anal. Chem., 79, 8350-8358, 2007.

Aiken, A. C., DeCarlo, P. F., Kroll, J. H., Worsnop, D. R., Huffman, J. A., Docherty, K., Ulbrich, I. M., Mohr, C., Kimmel, J. R., Sueper, D., Zhang, Q., Sun, Y., Trimborn, A., Northway, M., Ziemann, P. J., Canagaratna, M.R., Onasch, T. B., Alfarra, R., Prevot, A. S. H., Dommen, J., Duplissy, J., Metzger, A., Baltensperger, U., and Jimenez, J. L.: O/C and OM/OC Ratios

15 of Primary, Secondary, and Ambient Organic Aerosols with High Resolution Time-of-Flight Aerosol Mass Spectrometry, Environ. Sci. Technol. 42, 4478-4485, 2008.

Alfarra, M. R., Paulsen, D., Gysel, M., Garforth, A. A., Dommen, J., Prévôt, A. S. H., Worsnop, D. R., Baltensperger, U., and Coe, H.: A mass spectrometric study of secondary organic aerosols formed from the photooxidation of anthropogenic and biogenic precursors in a reaction chamber, Atmos. Chem. Phys., 6, 5279-5293, doi:10.5194/acp-6-5279-2006, 2006.

Alfarra, M. R., Prévôt, A. S. H., Szidat, S., Sandradewi, J., Weimer, S., Lanz, V., Schreiber, D., Mohr, M., and Baltensperger, U.: Identification of the mass spectral signature of organic aerosols from wood burning emissions, Environ. Sci. Technol. 41, 5770-5777, doi:10.1021/es062289b, 2007.

25 Andreae, M. O. and Merlet, P.: Emission of trace gases and aerosols from biomass burning, Global Biogeochem. Cy., 15, 955-966, doi:10.1029/2000GB001382, 2001.

Battye, W., and Battye, R.: Development of Emissions Inventory Methods for Wildland Fire, 91 pp., U.S. Environ. Prot. Agency, Chapel Hill, N. C., 2002.

Chakrabarty, R. K., Moosmüller, H., Garro, M. A., Arnott, W. P., Walker, J., Susott, R. A., Babbitt, R. E., Wold, C. E., Lincoln, E. N., and Hao, W. M.: Emissions from the laboratory

combustion of wildland fuels: Particle morphology and size, J. Geophys. Res. 111, D07204, doi:10.1029/2005JD006659, 2006.

Chen, L. W. A., Moosmüller, H., Arnott, W. P., Chow, J. C., and Watson, J. G.: Particle emissions from laboratory combustion of wildland fuels: In situ optical and mass measurements, Geophys. Res. Lett. 33, L04803, doi:10.1029/2005GL024838, 2006.

Chen, L. W. A., Moosmüller, H., Arnott, W. P., Chow, J. C., Watson, J. G., Susott, R. A., Babbitt, R. E., Wold, C. E., Lincoln, E. N. and Hao, W. M.: Emissions from laboratory combustion of wildland fuels: Emission factors and source profiles, Environ. Sci. Technol., 41, 4317-4325, doi:10.1021/es062364i, 2007.

10 Clinton, N. E., Gong, P., and Scott, K.: Quantification of pollutants emitted from very large wildland fires in southern California, USA, Atmos. Environ. 40, 3686-3695, doi:10.1016/j.atmosenv.2006.02.016, 2006.

Cofer, W. R., Levine, J. S., Riggan, P. J., Sebacher, D. I., Winstead, E. L., Shaw, E. F., Brass, J. A., and Ambrosia, V. G.: Trace gas emissions from a mid-latitude prescribed chaparral fire, J. Geophys. Res., 93, 1653-1658, doi:10.1029/JD093iD02p01653, 1988a.

Cofer, W. R., Levine, J. S., Sebacher, D. I., Winstead, E. L., Riggan, P. J., Brass, J. A., and Ambrosia, V. G.: Particulate-emissions from a mid-latitude prescribed chaparral fire, J. Geophys. Res., 93, 5207-5212, doi:10.1029/JD093iD05p05207, 1988b.

Crutzen, P. J. and Andreae, M. O.: Biomass burning in the tropics-impact on atmospheric chemistry and biogeochemical cycles, Science, 250, 1669-1678, doi:10.1126/science.250.4988.1669, 1990.

DeCarlo, P. F., Kimmel, J. R., Trimborn, A., Northway, M. J., Jayne, J. T., Aiken, A. C., Gonin, M., Fuhrer, K., Horvath, T., Docherty, K., Worsnop, D. R., and Jimenez, J. L.: Field-Deployable, High-Resolution, Time-of-Flight Aerosol Mass Spectrometer, Anal. Chem., 78, 8281-8289, 2006.

Fraser, M. P. and Lakshmanan, K.: Using levoglucosan as a molecular marker for the longrange transport of biomass combustion aerosols, Environ. Sci. Technol., 34, 4560-4564, 2000.

Friedli, H. R., Atlas, E., Stroud, V. R., Giovanni, L., Campos, T. and Radke, L. F.: Volatile organic

30 trace gases emitted from North American wildfires, Global Biogeochem. Cy., 15, 435-452, doi:10.1029/2000GB001328, 2001.

Habib, G., Venkataraman, C., Bond, T., and Schauer, J.: Chemical, microphysical and optical properties of primary particles from the combustion of biomass fuels, Environ. Sci. Technol., 
42, 8829-8834, 2008.

Haines, T. K., Busby, R. L., and Cleaves, D. A.: Prescribed burning in the south: Trends, purpose, and barriers, South. J. App. For., 25, 149-153, 2001.

Hays, M. D., Geron, C. D., Linna, K. J., Smith, N. D., and Schauer, J. J.: Speciation of gas-

5 phase and fine particle emissions from burning of foliar fuels, Environ. Sci. Technol., 36, 2281-2295, doi:10.1021/es0111683, 2002.

Mazzoleni, L. R., Zielinska, B., and Mossmueller, H.: Emissions of levoglucosan, methoxy phenols, and organic acids from prescribed burns, laboratory combustion of wildland fuels, and residential wood combustion, Environ. Sci. Technol., 41, 2115-2122, doi:10.1021/es061702c, 2007.

McMeeking, G. R., Kreidenweis, S. M., Lunden, M., Carrillo, J., Carrico, C. M., Lee, T.,Herckes, P., Engling, G., Day, D. E., Hand, J., Brown, N., Malm, W. C., and Collett Jr., J. L.: Smokeimpacted regional haze in California during the summer of 2002, Agric. For. Meteorol., 137, 25-42, doi:10.1016/j.agrformet.2006.01.011, 2006.

15 McMeeking, G. R., Kreidenweis, S. M., Baker, S., Carrico, C. M., Chow, J. C., Collett Jr., J. L., Hao, W. M., Holden, A. S., Kirchstetter, T. W., Malm, W. C., Moosmüller, H., Sullivan, A. P., and Wold, C. E.: Emissions of trace gases and aerosols during the open combustion of biomass in the laboratory, J. Geophys. Res. 114, D19210, doi:10.1029/2009JD011836, 2009.

20 Muhle, J., Lueker, T. J., Su, Y., Miller, B. R., Prather, K. A. and Weiss, R. F.: Trace gas and particulate emissions from the 2003 southern California wildfires, J. Geophys. Res., 112 D03307, doi:10.1029/2006JD007350, 2007.

Naeher, L. P., Brauer, M., Lipsett, M., Zelikoff, J. T., Simpson, C. D., Koenig, J. Q., and Smith, K. R.: Woodsmoke health effects: A review, Inhal. Toxicol., 19, 67-106, doi:10.1080/08958370600985875, 2007.

Park, R. J., Jacob, D. J., Kumar, N., and Yantosca, R. M.: Regional visibility statistics in the United States: Natural and transboundary pollution influences, and implications for the Regional Haze Rule, Atmos. Environ., 40, 5405-5423, doi:10.1016/j.atmosenv.2006.04.059, 2006.

30 Park, R. J., Jacob, D. J., and Logan, J. A.: Fire and biofuel contributions to annual mean aerosol mass concentrations in the United States, Atmos. Environ., 41, 7389-7400, doi:10.1016/j.atmosenv.2007.05.061, 2007.

Phuleria, H. C., Fine, P. M., Zhu, Y. F., and Sioutas, C.: Air quality impacts of the October 2003

8413

Southern California wildfires, J. Geophys. Res., 110, D07S20, doi:10.1029/2004JD004626, 2005

Puxbaum, H., Rendl, J., Allabashi, R., Otter, L., and Scholes, M.: Mass balance of the atmospheric aerosol in a South African subtropical savanna (Nylsvley May 1997), J. Geophys. Res., 105, 697-706, 2000.

Reid, J. S., Koppmann, R., Eck, T. F., and Eleuterio, D. P.: A review of biomass burning emissions part II: intensive physical properties of biomass burning particles, Atmos. Chem. Phys., 5, 799-825, doi:10.5194/acp-5-799-2005, 2005.

Robinson, A. L., Subramanian, R., Donahue, N. M., Bernardo-Bricker, A., and Rogge, W. F.:

10 Source apportionment of molecular markers and organic aerosol. 2. Biomass smoke, Environ. Sci. Technol., 40, 7811-7819, doi:10.1021/es060782h, 2006.

Rogge, W., Mazurek, M., Hildemann, L., Cass, G., and Simoneit, B. R. T.: Quantification of urban organic aerosols at a molecular level: Identification, abundance and seasonal variation, Atmos. Environ., 27A, 1309-1330, 1993.

15 Simoneit, B. R. T.: Biomass burning - A review of organic tracers for smoke from incomplete combustion, Appl. Chem., 17, 129-162, 2002.

Simoneit, B. R. T., Schauer, J. J., Nolte, C. G., Oros, D. R., Elias, V. O., Fraser, M. P., Rogge, W. F., and Cass, G. R.: Levoglucosan, a tracer for cellulose in biomass burning and atmospheric particles, Atmos. Environ., 33, 173-182, doi:10.1016/S1352-2310(98)00145-9, 1999.

20 Spracklen, D. V., Logan, J. A., Mickley, L. J., Park, R. J., Yevich, R., Westerling, A. L., and Jaffe, D. A.: Wildfires drive interannual variability of organic carbon aerosol in the western U.S. in summer, Geophys. Res. Lett., 34, L16816, doi:10.1029/2007GL030037, 2007.

van der Werf, G. R., Randerson, J. T., Giglio, L., Collatz, G. J., Kasibhatla, P. S., and Arellano Jr., A. F.: Interannual variability in global biomass burning emissions from 1997 to 2004, Atmos. Chem. Phys., 6, 3423-3441, doi:10.5194/acp-6-3423-2006, 2006.

Ward, D. E. and Radke, L. F.: Emission measurements from vegetation fires: A comparative evaluation of methods and results, in Fire in the Environment: The Ecological, Atmospheric, and Climatic Importance of Vegetation Fires, edited by: Crutzen, P. J. and Goldammer, J.-G., 53-76, John Wiley, Chichester, UK, 1993.

30 Watson, J. G.: Visibility: Science and regulation, J. Air Waste Manage. Assoc., 52, 628-713, 2002.

Weimer, S., Alfarra, M.R., Schreiber, D., Mohr, M., Prévôt, A.S., and Baltensperger, U.: Organic aerosol mass spectral signatures from wood-burning emissions: influence of burning 
conditions and wood type, J. Geophys. Res., 113, D10303, doi:10.1029/2007JD009309, 2008.

Weise, D. R., Zhou, X. Y., Sun, L. L. and Mahalingam, S.: Fire spread in chaparral - "go or no-go?", Int. J. Wildland Fire, 14, 99-106, 2005.

5 Yokelson, R. J., Griffith, D. W. T. and Ward, D. E.: Open-path Fourier transform infrared studies of large-scale laboratory biomass fires, J. Geophys. Res., 101, 21067-21080, doi:10.1029/96JD01800, 1996.

Yokelson, R. J., Goode, J. G., Ward, D. E., Susott, R. A., Babbitt, R. E., Wade, D. D., Bertschi, I., Griffith, D. W. T. and Hao, W. M.: Emissions of formaldehyde, acetic acid, methanol, and other trace gases from biomass fires in North Carolina measured by airborne Fourier transform infrared spectroscopy, J. Geophys. Res., 104, 30109-30125, doi:10.1029/1999JD900817, 1999.

Table 1. Plant species used as biomass fuels in this study.

\begin{tabular}{|c|c|}
\hline Fuel Type & Plant Species \\
\hline Chamise & Adenostoma fasciculatum, Quercus berberidifolia \\
\hline Ceanothus & Ceanothus leucodermis \\
\hline Maritime chaparral & $\begin{array}{l}\text { Ceanothus impressus var. impressus, C. cuneatus } \\
\text { var. fascicularis, Salvia mellifera }\end{array}$ \\
\hline Coastal sage scrub & $\begin{array}{l}\text { Salvia mellifera, Ericameria ericoides, Artemisia } \\
\text { californica }\end{array}$ \\
\hline California sagebrush & Artemisia californica, Ericameria ericoides \\
\hline Manzanita & Arctostaphylos rudis, Arctostaphylos purissima \\
\hline Oak savanna & Quercus emoryi, Eragrostis lehmanniana \\
\hline Oak woodland & Quercus emoryi, Arctostaphylos pungens \\
\hline Masticated mesquite & Prosopis velutina, Baccharis sarothroides \\
\hline
\end{tabular}


Table 2. Fuel bed properties for the 9 plant species.

\begin{tabular}{lrrrrrr}
\hline Fuel Type & $\begin{array}{r}\text { \# of } \\
\text { Burns }\end{array}$ & $\begin{array}{r}\text { Moisture } \\
\text { content }(\%)\end{array}$ & $\begin{array}{r}\text { Fuel bed } \\
\text { mass }(\mathrm{g})\end{array}$ & $\begin{array}{r}\text { Bulk density } \\
\left(\mathrm{kg} \mathrm{m}^{-3}\right)\end{array}$ & $\begin{array}{r}\text { Packing } \\
\text { ratio }\end{array}$ & $\begin{array}{r}\text { Mass } \\
\text { consumption }(\%)\end{array}$ \\
\hline Chamise & 6 & 11.9 & 2079 & 8.6 & 0.015 & 38 \\
Ceanothus & 6 & 10.2 & 2007 & 5.8 & 0.01 & 54 \\
Maritime chaparral & 5 & 11.2 & 2871 & 7.5 & 0.013 & 95 \\
Coastal sage scrub & 5 & 9.3 & 2299 & 6.0 & 0.01 & 95 \\
California sagebrush & 6 & 9.0 & 2460 & 6.4 & 0.011 & 93 \\
Manzanita & 6 & 12.6 & 2906 & 7.6 & 0.013 & 94 \\
Oak savanna & 5 & 14.3 & 2788 & 7.3 & 0.012 & 95 \\
Oak woodland & 5 & 32.8 & 2054 & 5.3 & 0.009 & 92 \\
Masticated mesquite & 5 & 4.3 & 1831 & 14.3 & 0.024 & \\
\hline
\end{tabular}

8417

Table 3. Ratios of $m / z 29,43,44,60$ and 73 for all nine fuels (a) flaming; (b) mixed; (c) smoldering.

\begin{tabular}{|c|c|c|c|c|c|}
\hline \multicolumn{6}{|l|}{ (a) } \\
\hline Fuel Type & $\begin{array}{r}m / z 29 / o r g \\
(\%)\end{array}$ & $\begin{array}{r}m / z 43 / \text { org } \\
(\%)\end{array}$ & $\begin{array}{r}m / z 44 / \text { org } \\
(\%)\end{array}$ & $\begin{array}{r}m / z 60 / o r g \\
(\%)\end{array}$ & $\begin{array}{r}m / z 73 / o r g \\
(\%)\end{array}$ \\
\hline chamise & 3.62 & 6.07 & 9.30 & 0.72 & 0.69 \\
\hline CA sage & 1.79 & 2.91 & 6.47 & 0.44 & 0.27 \\
\hline Coastal sage & 4.47 & 3.35 & 9.19 & 0.77 & 0.40 \\
\hline Oak savanna & 2.27 & 4.60 & 5.58 & 0.76 & 0.31 \\
\hline Oak woodland & 3.72 & 4.12 & 8.93 & 0.90 & 0.61 \\
\hline mesquite & 3.19 & 4.10 & 5.97 & 0.60 & 0.51 \\
\hline ceanothus & 4.33 & 7.06 & 5.76 & 0.93 & 0.77 \\
\hline Manzanita & 3.63 & 5.00 & 11.51 & 0.98 & 0.80 \\
\hline Maritime chaparral & 1.90 & 3.15 & 5.21 & 0.54 & 1.11 \\
\hline \multicolumn{6}{|l|}{ (b) } \\
\hline chamise & 4.87 & 5.48 & 4.10 & 1.24 & 0.94 \\
\hline CA sage & 2.67 & 3.66 & 6.14 & 0.55 & 0.53 \\
\hline Coastal sage & 2.49 & 4.12 & 9.34 & 0.89 & 0.58 \\
\hline Oak savanna & 4.27 & 3.51 & 4.09 & 1.50 & 1.30 \\
\hline Oak woodland & 3.89 & 4.24 & 2.88 & 1.22 & 0.66 \\
\hline mesquite & 4.04 & 4.58 & 4.61 & 1.03 & 0.77 \\
\hline ceanothus & 5.96 & 4.76 & 2.72 & 1.43 & 1.30 \\
\hline Manzanita & 3.71 & 4.37 & 14.68 & 0.36 & 0.36 \\
\hline Maritime chaparral & 3.90 & 5.07 & 1.84 & 1.12 & 0.66 \\
\hline \multicolumn{6}{|l|}{ (c) } \\
\hline chamise & 4.72 & 5.45 & 2.25 & 1.23 & 0.92 \\
\hline CA sage & 0 & 6.35 & 6.90 & 1.28 & 0.94 \\
\hline Coastal sage & 4.58 & 5.83 & 0 & 1.13 & 1.12 \\
\hline Oak savanna* & NA & NA & NA & NA & NA \\
\hline Oak woodland & 3.31 & 5.09 & 1.44 & 1.10 & 0.76 \\
\hline mesquite & 7.89 & 3.78 & 4.20 & 0.09 & 0.22 \\
\hline ceanothus & 6.18 & 0.81 & 2.38 & 0.73 & 0.18 \\
\hline Manzanita & 2.67 & 3.50 & 17.15 & 0.75 & 0.71 \\
\hline Maritime chaparral & 2.87 & 5.57 & 1.41 & 0.68 & 0.49 \\
\hline
\end{tabular}

Note: ${ }^{*}$ no obvious smoldering phase observed for this fuel 
Table 4. Empirical formula for nine biomass fuels during flaming, mixed and smoldering phases.

\begin{tabular}{|c|c|c|c|}
\hline \multirow[t]{2}{*}{ Fuel type } & \multicolumn{3}{|c|}{ Empirical Formula } \\
\hline & Flaming & Mixed & Smoldering \\
\hline $\begin{array}{l}\text { Chamise } \\
\text { California Sage brush } \\
\text { California Sage scrub } \\
\text { Oak Savanna } \\
\text { Oak Woodland } \\
\text { Masticated mesquite } \\
\text { Ceanothus } \\
\text { Manzanita } \\
\text { Maritime chaparral }\end{array}$ & $\begin{array}{l}\mathrm{CH}_{1.62 \pm 0.07} \mathrm{~N}_{0.03 \pm 0.01} \mathrm{O}_{0.32 \pm 0.09} \\
\mathrm{CH}_{1.56 \pm 0.07} \mathrm{~N}_{0.03 \pm 0.01} \mathrm{O}_{0.36 \pm 0.07} \\
\mathrm{CH}_{1.43 \pm 0.09} \mathrm{~N}_{0.04 \pm 0.01} \mathrm{O}_{0.48 \pm 0.07} \\
\mathrm{CH}_{1.65 \pm 0.10} \mathrm{~N}_{0.20 \pm 0.15} \mathrm{O}_{0.35 \pm 0.07} \\
\mathrm{CH}_{1.56 \pm 0.07} \mathrm{~N}_{0.13 \pm 0.08} \mathrm{O}_{0.31 \pm 0.08} \\
\mathrm{CH}_{1.65 \pm 0.09} \mathrm{~N}_{0.21 \pm 0.11} \mathrm{O}_{0.25 \pm 0.05} \\
\mathrm{CH}_{1.62 \pm 0.11} \mathrm{~N}_{0.03 \pm 0.01} \mathrm{O}_{0.27 \pm 0.05} \\
\mathrm{CH}_{1.76 \pm 0.11} \mathrm{~N}_{0.32 \pm 0.16} \mathrm{O}_{0.20 \pm 0.05} \\
\mathrm{CH}_{1.59 \pm 0.08} \mathrm{~N}_{0.05 \pm 0.04} \mathrm{O}_{0.35 \pm 0.07}\end{array}$ & $\begin{array}{l}\mathrm{CH}_{1.61 \pm 0.04} \mathrm{~N}_{0.02 \pm 0.01} \mathrm{O}_{0.24 \pm 0.03} \\
\mathrm{CH}_{1.52 \pm 0.08} \mathrm{~N}_{0.04 \pm 0.03} \mathrm{O}_{0.34 \pm 0.08} \\
\mathrm{CH}_{1.48 \pm 0.19} \mathrm{~N}_{0.13 \pm 0.08} \mathrm{O}_{0.43 \pm 0.12} \\
\mathrm{CH}_{1.68 \pm 0.12} \mathrm{~N}_{0.20 \pm 0.17} \mathrm{O}_{0.22 \pm 0.09} \\
\mathrm{CH}_{1.62 \pm 0.07} \mathrm{~N}_{0.12 \pm 0.08} \mathrm{O}_{0.20 \pm 0.07} \\
\mathrm{CH}_{1.71 \pm 0.12} \mathrm{~N}_{0.31 \pm 0.17} \mathrm{O}_{0.23 \pm 0.07} \\
\mathrm{CH}_{1.1 \pm \pm 0.15} \mathrm{~N}_{0.08 \pm 0.07} \mathrm{O}_{0.30 \pm 0.07} \\
\mathrm{CH}_{1.58 \pm 0.15} \mathrm{~N} \mathrm{CH}_{1.71 \pm 0.11} \mathrm{~N}_{0.38 \pm 0.19} \mathrm{O}_{0.38 \pm 0.07} \\
\mathrm{CH}_{1.64 \pm 0.02} \mathrm{~N}_{0.04 \pm 0.02} \mathrm{O}_{0.17 \pm 0.05}\end{array}$ & $\begin{array}{l}\mathrm{CH}_{1.67 \pm 0.04} \mathrm{~N}_{0.09 \pm 0.09} \mathrm{O}_{0.18 \pm 0.05} \\
\mathrm{CH}_{1.51 \pm 0.15} \mathrm{~N}_{0.08 \pm 0.04} \mathrm{O}_{0.36 \pm 0.09} \\
\mathrm{CH}_{1.61 \pm 0.25} \mathrm{~N}_{0.13 \pm 0.10} \mathrm{O}_{0.27 \pm 0.20} \\
\mathrm{NA}^{*} \\
\mathrm{CH}_{1.74 \pm 0.09} \mathrm{~N}_{0.19 \pm 0.15} \mathrm{O}_{0.14 \pm 0.05} \\
\mathrm{CH}_{1.81 \pm 0.14} \mathrm{~N}_{0.38 \pm 0.18} \mathrm{O}_{0.23 \pm 0.07} \\
\mathrm{CH}_{1.49 \pm 0.22} \mathrm{~N}_{0.14 \pm 0.14} \mathrm{O}_{0.30 \pm 0.14} \\
\mathrm{CH}_{1.75 \pm 0.07} \mathrm{~N}_{0.52 \pm 0.13} \mathrm{O}_{0.37 \pm 0.09} \\
\mathrm{CH}_{1.68 \pm 0.08} \mathrm{~N}_{0.07 \pm 0.06} \mathrm{O}_{0.15 \pm 0.10}\end{array}$ \\
\hline
\end{tabular}

Note: * no obvious smoldering phase observed for this fuel

Table 5. Summary of univariate tests of significance of combustion phase and fuel type effects on emission ratios.

\begin{tabular}{lllll}
\hline Effect & \multicolumn{4}{c}{ Elemental Ratio } \\
\cline { 2 - 5 } & $\mathrm{OM} / \mathrm{OC}$ & $\mathrm{O} / \mathrm{C}$ & $\mathrm{H} / \mathrm{C}$ & $\mathrm{N} / \mathrm{C}$ \\
\hline Combustion Phase (all phases equal) & $\mathrm{Y}^{\mathrm{a}}$ & $\mathrm{Y}$ & $\mathrm{Y}$ & $\mathrm{Y}$ \\
Flaming versus smoldering & $\mathrm{N}$ & $\mathrm{N}$ & $\mathrm{N}$ & $\mathrm{Y}$ \\
Flaming versus mixed & $\mathrm{N}$ & $\mathrm{N}$ & $\mathrm{N}$ & $\mathrm{N}$ \\
Fuel Type (all fuel types equal) & $\mathrm{N}$ & $\mathrm{N}$ & $\mathrm{N}$ & $\mathrm{Y}$ \\
Hard chaparral $^{b}$ & $\mathrm{~N}$ & $\mathrm{~N}$ & $\mathrm{~N}$ & $\mathrm{Y}$ \\
Hard chaparral versus soft chaparral $_{\text {Hard chaparral versus Emory oak woodland }}$ & $\mathrm{N}$ & $\mathrm{Y}$ & $\mathrm{Y}$ & $\mathrm{N}$ \\
Emory oak woodland versus oak savanna $_{\text {Emory oak woodland versus masticated mesquite }}$ & $\mathrm{N}$ & $\mathrm{N}$ & $\mathrm{N}$ & $\mathrm{N}$ \\
Emory on & $\mathrm{N}$ & $\mathrm{N}$ & $\mathrm{N}$ \\
\hline
\end{tabular}

Note: ${ }^{a} \mathrm{Y}$ indicates that the hypothesis that the effect is equal to 0 was rejected; $\mathrm{N}$ indicates that the hypothesis was not rejected at the 0.05 level.

${ }^{\mathrm{b}}$ Hard chaparral fuel types are chamise/scrub oak, ceanothus, manzanita, maritime chaparral, soft chaparral fuel types are coastal sage scrub and California sagebrush. 
Table 6. Summary of multivariate tests of significance of combustion phase and fuel type effects on emission ratios (4 emission ratios tested collectively which considers the correlation between the ratios).

\begin{tabular}{ll}
\hline Effect & Significance \\
\hline Combustion Phase (all phases equal) & $\mathrm{Y}^{\mathrm{a}}$ \\
Flaming versus smoldering & $\mathrm{Y}$ \\
Flaming versus mixed & $\mathrm{Y}$ \\
\hline Fuel Type (all fuel types equal) & $\mathrm{Y}$ \\
Hard chaparral & $\mathrm{N}$ \\
Hard chaparral versus soft chaparral & $\mathrm{Y}$ \\
Hard chaparral versus Emory oak woodland & $\mathrm{N}$ \\
Emory oak woodland versus oak savannah & $\mathrm{N}$ \\
Emory oak woodland versus masticated mesquite & $\mathrm{N}$ \\
\hline
\end{tabular}

Note: ${ }^{a} \mathrm{Y}$ indicates that the hypothesis that the effect is equal to 0 was rejected; $\mathrm{N}$ indicates that the hypothesis was not rejected at the 0.05 level.

${ }^{\mathrm{b}}$ Hard chaparral fuel types are chamise/scrub oak, ceanothus, manzanita, maritime chaparral, soft chaparral fuel types are coastal sage scrub and California sagebrush
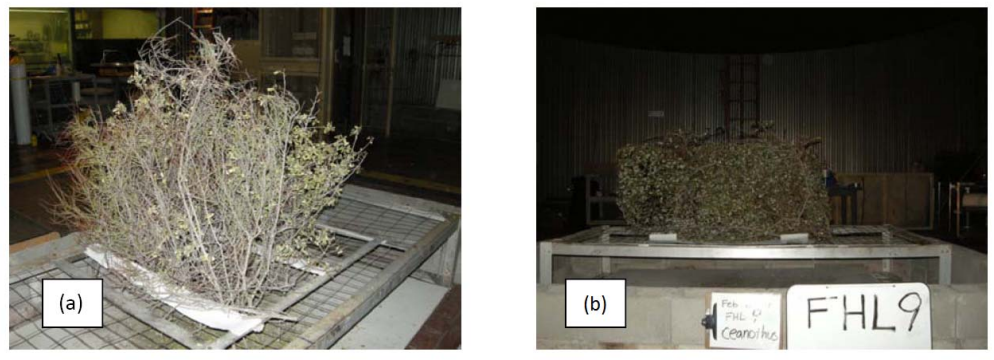

Fig. 1. Fuel bed arrangements (a): vertical arrangement of Chamise/scrub oak (b): horizontal arrangements of biomass fuel. 


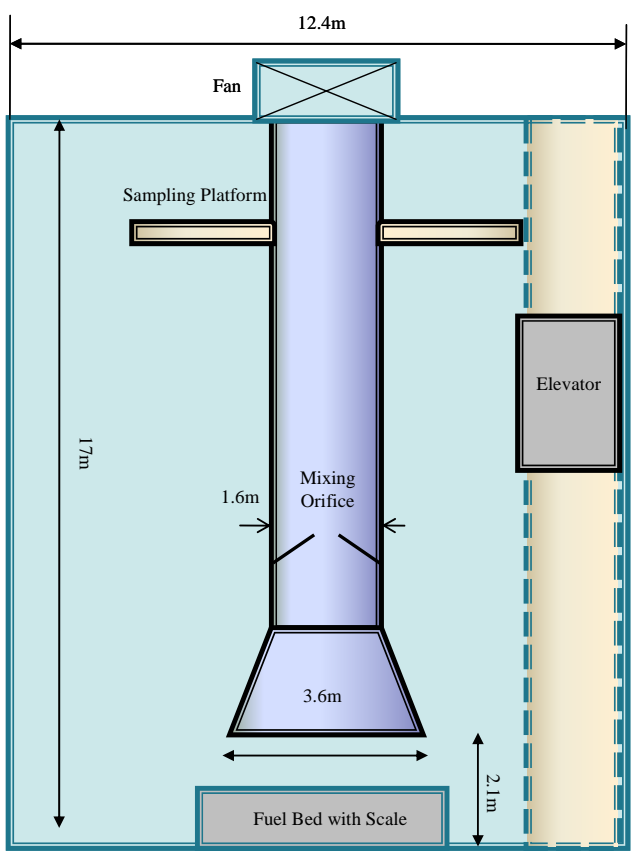

Fig. 2. Schematic of the US Forest Service Science Laboratory combustion facility at Missoula, MT.

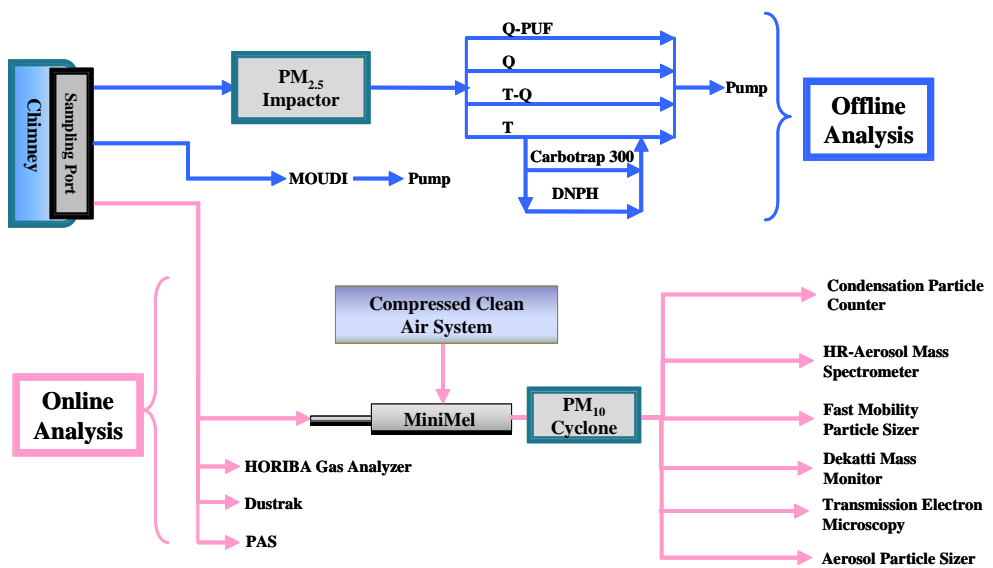

Fig. 3. Schematic diagram of online and offline sampling systems. 


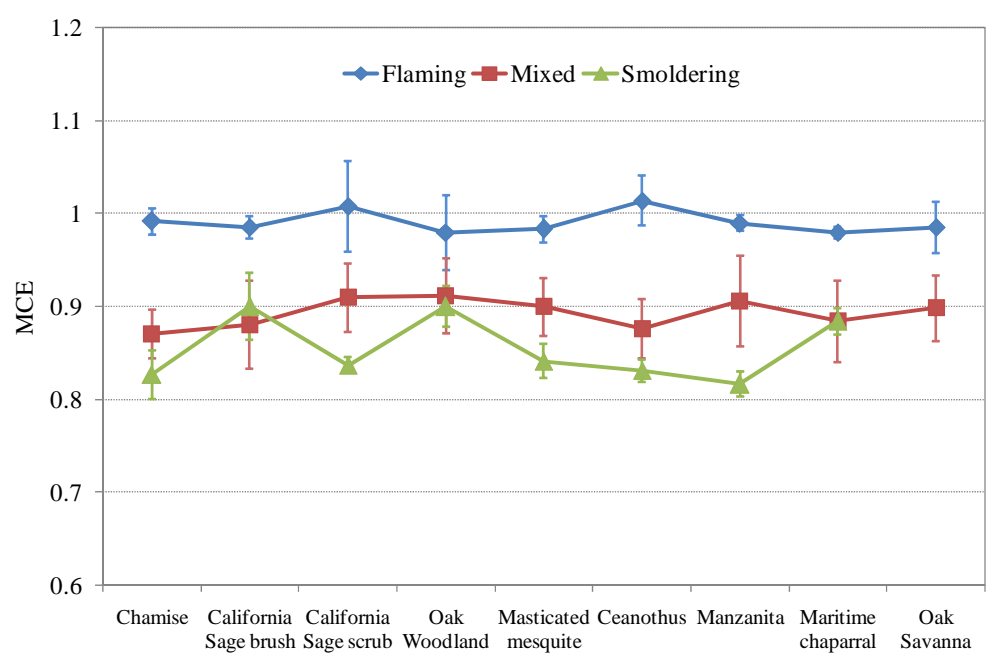

Fig. 4. Averaged MCE for 9 fuel species during flaming, mixed and smoldering phases.

(a)
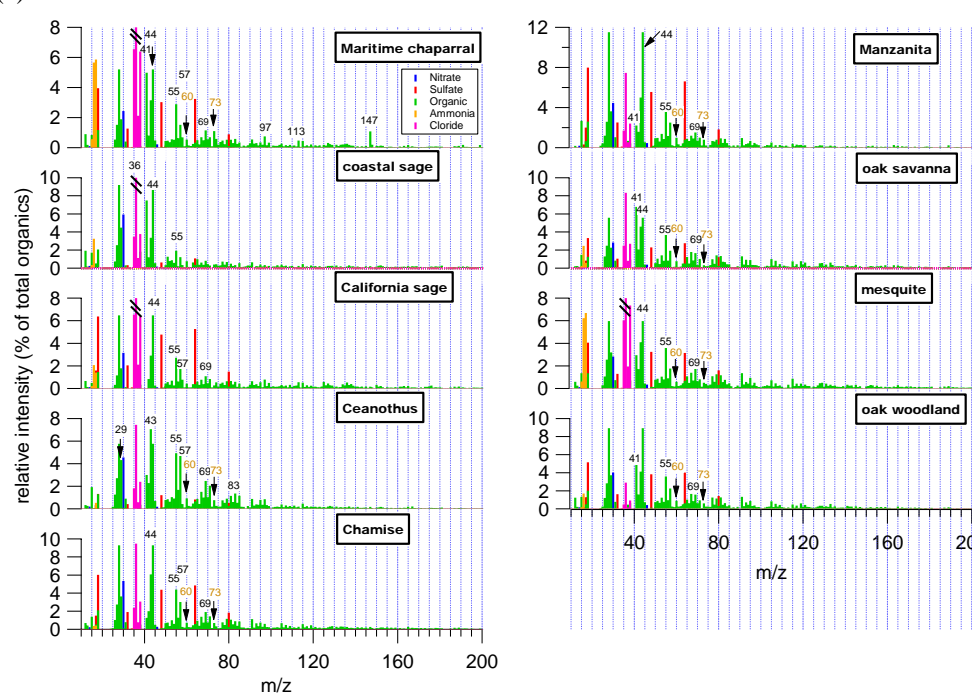

$8-$
6
4
2
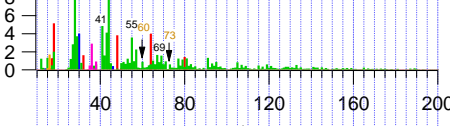
(b)
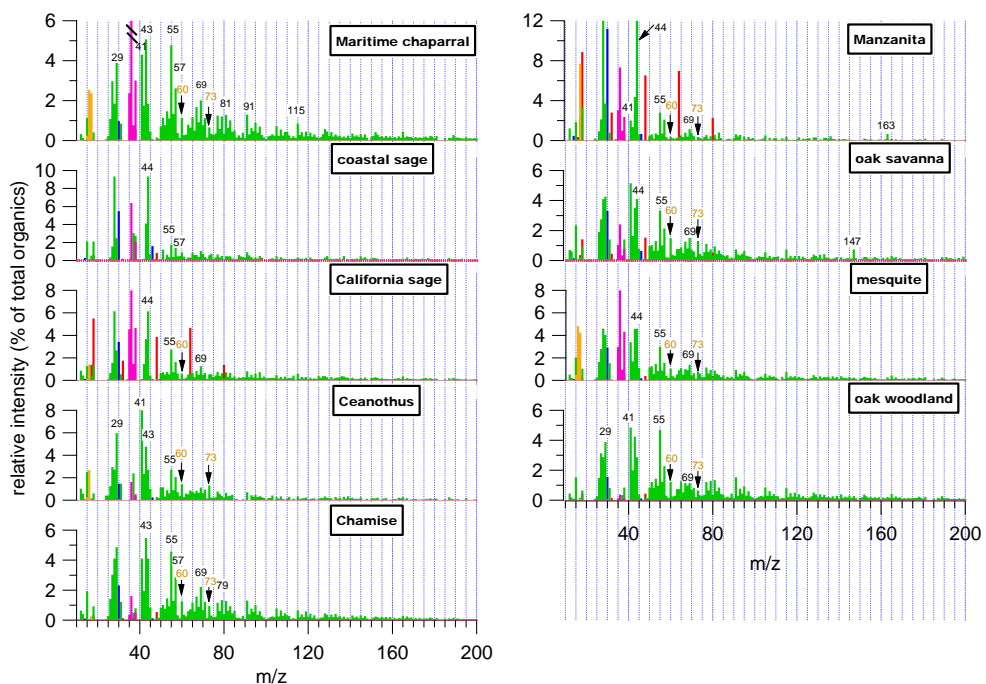

Fig. 5b. Normalized mass spectra for mixed phase of measured particle components from the combustion of different biomass fuels.

(c)

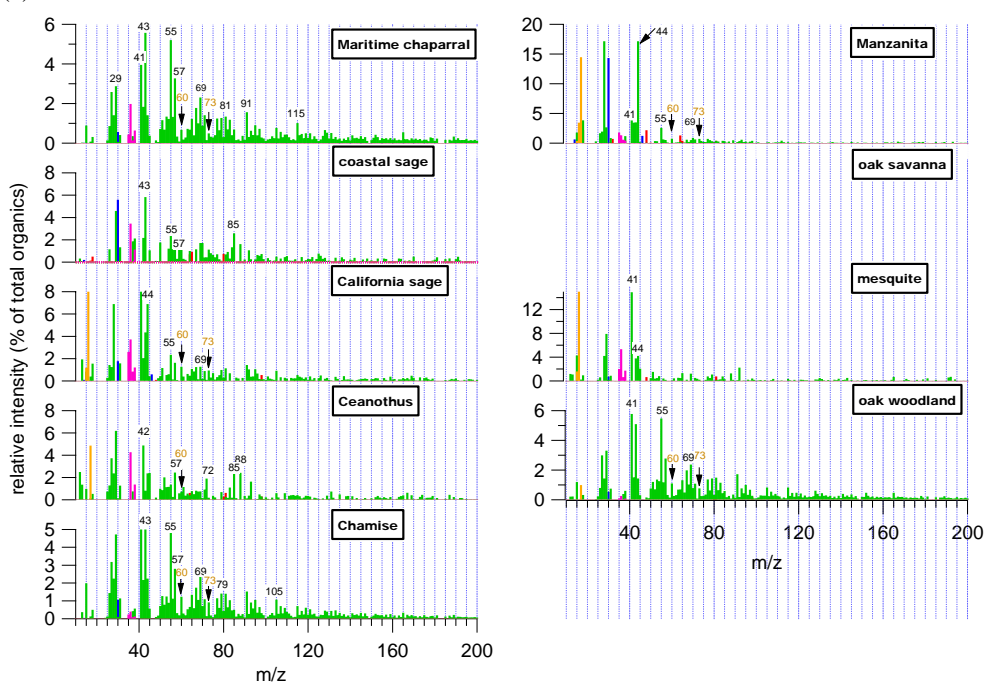

Fig. 5c. Normalized mass spectra for smoldering phase of measured particle components from the combustion of different biomass fuels. 

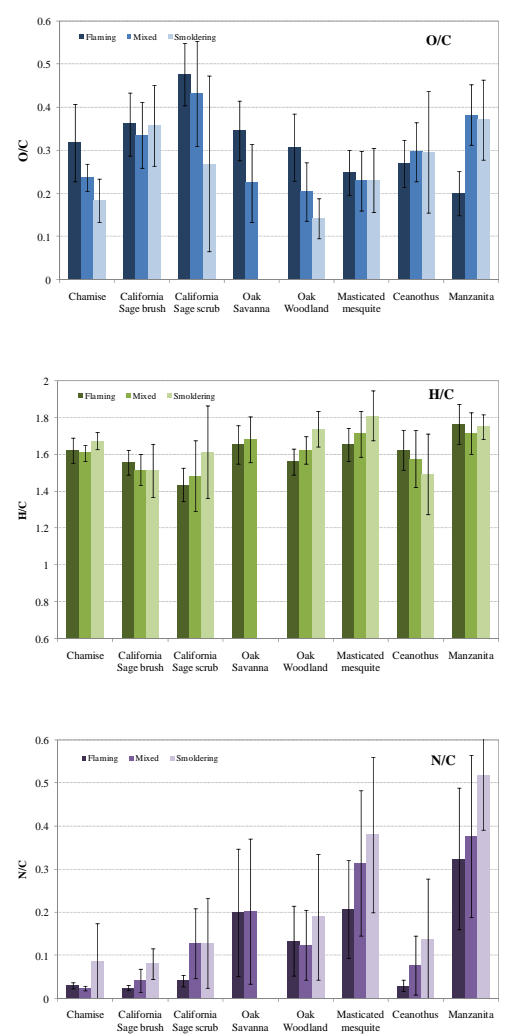

Fig. 6. Averaged elemental ratios of organic carbonaceous aerosol from the combustion of different biomass fuels.

\section{9}
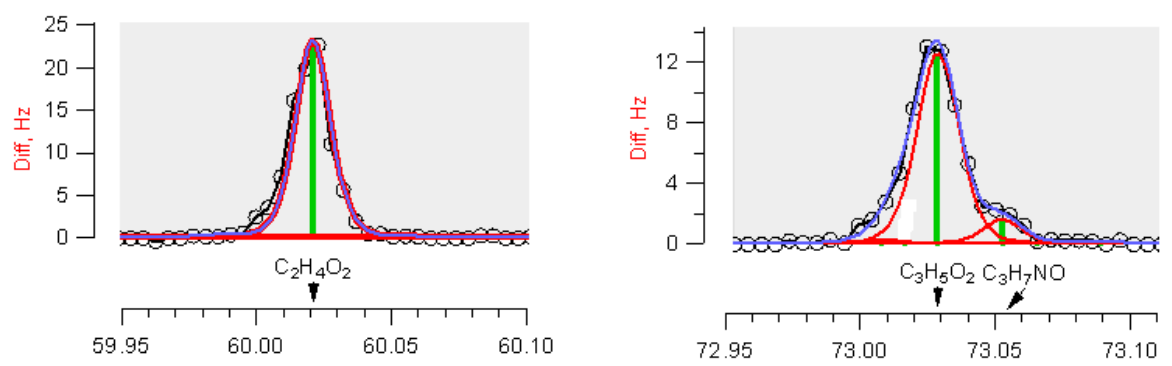

Fig. 7. Peaks resolved for $m / z 60$ and 73 from Chamise burning. 
(a)
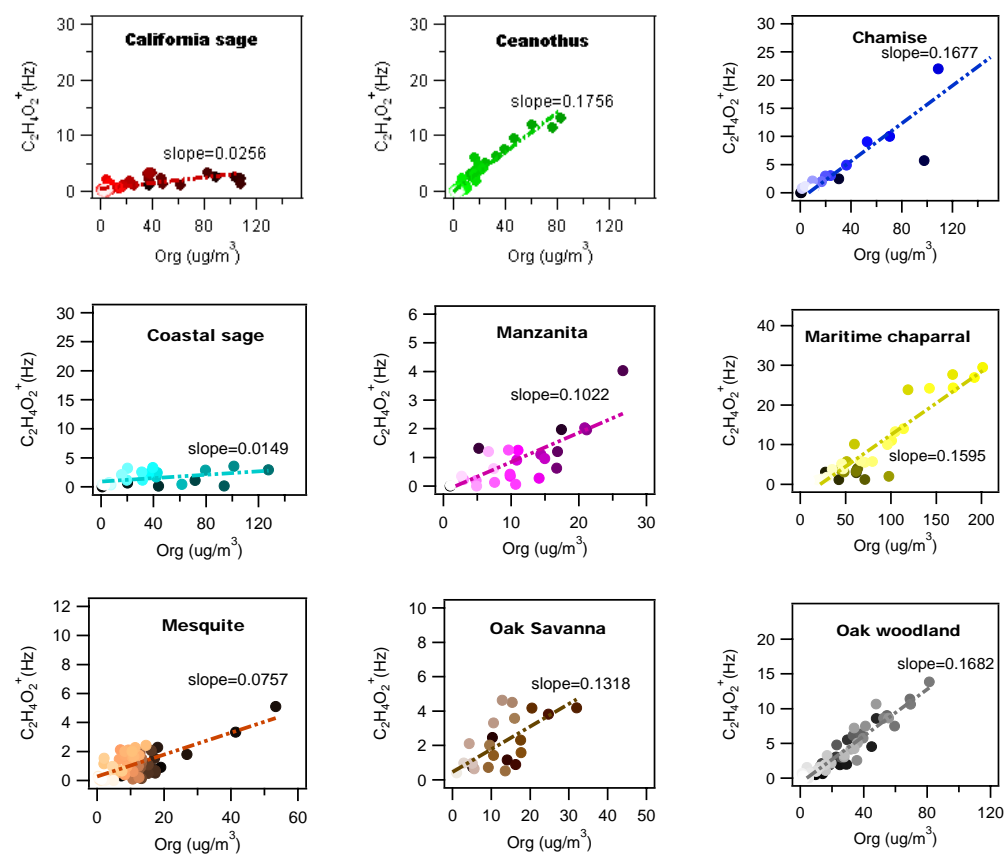

Fig. 8a. Time evolution of $\mathrm{C}_{2} \mathrm{H}_{4} \mathrm{O}_{2}^{+}$ions vs. total organics of aerosol emissions for nine biomass fuels.

(b)
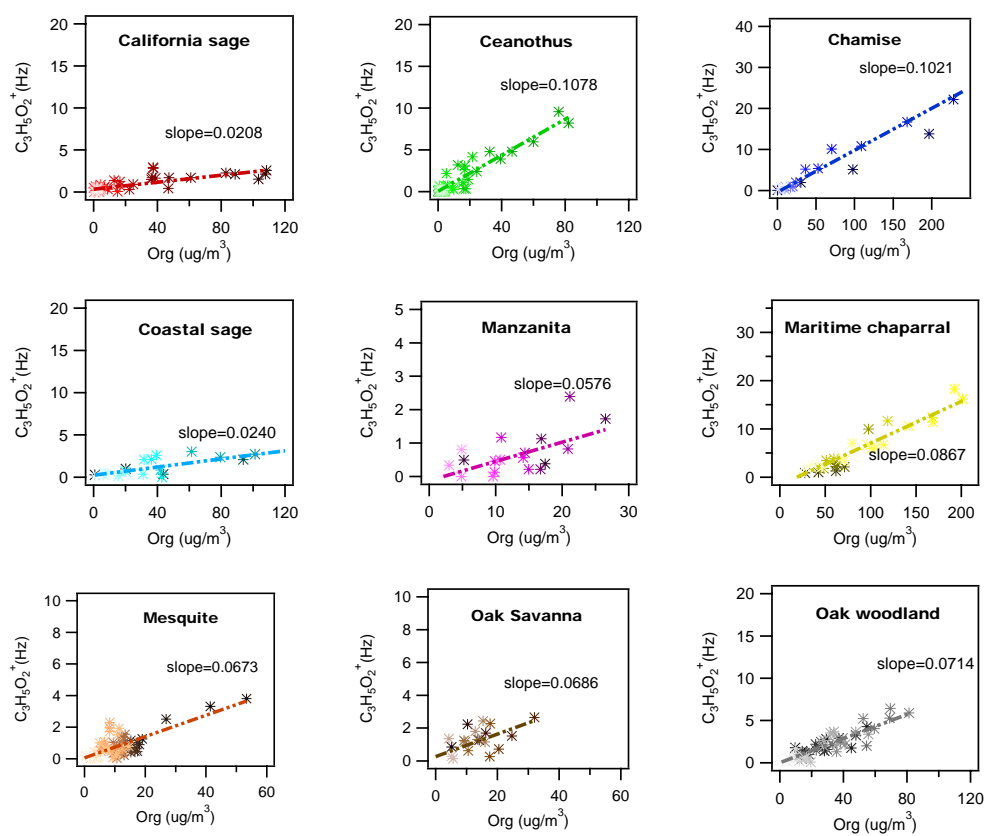

Fig. 8b. Time evolution of $\mathrm{C}_{3} \mathrm{H}_{5} \mathrm{O}_{2}^{+}$ions vs. total organics of aerosol emissions for nine biomass fuels. 